\title{
The effects of parental rearing styles and early maladaptive schemas in the development of personality: a systematic review
}

\author{
O efeito dos estilos parentais e esquemas desadaptativos precoces no \\ desenvolvimento da personalidade: uma revisão sistemática
}

Lissia Ana Basso, ${ }^{1}$ (D) Amanda Borges Fortes, ${ }^{2}$ Cintia Pacheco e Maia, ${ }^{2}$ Elisa Steinhorst,${ }^{1}$ (D) Ricardo Wainer ${ }^{1}$

\begin{abstract}
Introduction: The present paper aims to identify and characterize studies that assess the repercussions of parental rearing styles on development of psychopathological symptoms and to examine the possible relations between parental rearing behaviors and development of early maladaptive schemas (EMS).

Methods: A systematic search was conducted on the PsychNet, BVS, Scopus, Web of Science and PubMed databases for empirical studies published up to 2018 in Portuguese, English, or Spanish that investigated and characterized the effects of parental rearing styles.

Results: The electronic search identified 321 articles on the various different databases, only 22 of which met the criteria for inclusion and were read in full. Correlations were found between EMS and maternal rejection, parental rearing styles and depression in the studies. EMS were also found to act as mediators in the relationship between parental rearing styles and/or education and dysfunctional symptoms during personality development.

Conclusions: In the studies selected, parental rearing styles stood out from other variables that influence personality development and activation of schematic patterns. It is therefore important to highlight the importance of conducting studies in this area to provide information that can promote care and prevention strategies in early childhood.
\end{abstract}

Keywords: Early maladaptive schemas, parental styles, personality.
Resumo

Introdução: O objetivo do presente artigo é identificar e caracterizar estudos que avaliem a repercussão dos estilos parentais na formação de sintomas psicopatológicos e verificar uma possível relação dos padrões parentais com o desenvolvimento dos esquemas iniciais desadaptativos (EIDs).

Método: Uma busca sistemática foi realizada nas seguintes bases de dados: PsychNet, BVS, Scopus, Web of Science e PubMed. Foram buscados estudos empíricos publicados até 2018, escritos em português, inglês ou espanhol, que investigassem e caracterizassem os efeitos dos estilos parentais.

Resultados: A busca eletrônica identificou 321 artigos nas diferentes bases de dados, dentre os quais apenas 22 preencheram os critérios de seleção e foram lidos na íntegra. Os estudos demonstraram que há correlação entre EIDs, rejeição materna, estilos parentais e depressão. Também foi encontrada a participação dos EIDs como mediadores na relação entre estilos parentais e/ou educação e sintomas disfuncionais na formação da personalidade.

Conclusão: Nos estudos selecionados, estilos parentais se destacaram entre as variáveis envolvidas na formação da personalidade e ativação dos padrões esquemáticos. Portanto, frisa-se a importância de estudos na área, a fim de aprofundar conhecimentos para promover saúde e melhores estratégias de prevenção em crianças.

Descritores: Esquemas iniciais desadaptativos, estilos parentais, personalidade.

\footnotetext{
${ }^{1}$ Wainer Psicologia Cognitiva, Porto Alegre, RS, Brazil. 2 Pontifícia Universidade Católica do Rio Grande do Sul (PUCRS), Porto Alegre, RS, Brazil. Submitted Sep 14 2017, accepted for publication Jan 172019.

Suggested citation: Basso LA, Fortes AB, Maia CP, Steinhorst E, Wainer R. The effects of parental rearing styles and early maladaptive schemas in the development of personality: a systematic review. Trends Psychiatry Psychother. 2019;41(3):301-313. http://dx.doi.org/10.1590/2237-6089-2017-0118
} 


\section{Introduction}

From the moment a baby is born, his/her parents, or caregivers, are the main source of nurturance, protection and education. The parents' behaviors with regard to discipline, hierarchy and emotional support are what we call parental rearing style, or behavior. ${ }^{1}$

Jeffrey Young, founder of Schema Therapy, suggests that in order to become psychologically healthy adults, it is important that our core psychological needs are adequately met by our parents/caregivers during childhood. In cases of parental neglect these needs are frustrated and the probability of the child developing early maladaptive schemas (EMS) is higher. EMS are rigid mental structures, comprising emotions, cognitions, bodily sensations and memories that are formed and maintained by ongoing patterns of damaging experiences with relevant individuals. Maladaptive schemas start to form in early childhood and become a guide for the organization of incoming information, being elaborated and gaining stability throughout one's lifetime. ${ }^{2}$

Among the biological, environmental and social variables responsible for development of these patterns, parental rearing styles are especially relevant. Extensive research, in studies with various different foci, has investigated parental rearing styles/behaviors and their repercussions for the development of children and adolescents. ${ }^{1,3-5}$ According to Carvalho \& Silva, ${ }^{6}$ parental rearing styles are capable of minimizing or maximizing the impact of social and biological variables on personality development. However, the authors of the present study were unable to find studies assessing these variables and focusing on EMS, or other aspects of personality.

Taking into account the above, and adopting the Schema Therapy model as a foundation, this paper aims to emphasize the importance of characterizing family functioning to better understand the problems of clients presenting at centers providing psychiatric and psychological services. Moreover, due to the limited number of manuscripts published on the aforementioned subject and model, it is extremely relevant to identify and characterize studies that do assess the repercussions of parental rearing styles for development of anxiety, humor and personality disorder symptoms and to examine the possible relations between parental rearing behaviors and development of EMS.

\section{Methods}

In the present study, the authors searched for empirical studies published up to 2018 in Portuguese, English or Spanish that investigated and characterized the effects of parental rearing styles and their relationship with Early Maladaptive Schemas in participants with no age limits.

For this purpose, the PsychNet, BVS, Scopus, Web of Science and PubMed databases were used. The descriptors adopted were [early maladaptive schemas] OR [schema therapy] OR [Young Schema Questionnaire] OR [Young Parental Inventory] AND [rearing styles] OR [parenting styles] OR [child rearing] AND [psychopathology] OR [personality disorder] OR [symptoms].

The inclusion criteria were: a) empirical studies; b) studies written in English, Portuguese or Spanish; c) studies whose dependent variable was EMS; and d) studies in which the repercussions of parental rearing styles were presented. The lead evaluator excluded duplicate articles and non-scientific articles. Two evaluators read the articles' titles and abstracts; in case of disagreement between the two evaluators, a third evaluator assessed the abstracts. After this step, manuscripts that did not meet the inclusion criteria were excluded. Subsequently, the lead evaluator and a third evaluator read the materials carefully, selecting manuscripts that met the inclusion criteria. The exclusion criteria were: a) studies of effectiveness/ efficacy of intervention; b) studies in languages other than English, Spanish or Portuguese; and c) studies that did not investigate parental rearing styles.

\section{Results}

\section{Article selection}

The electronic search identified 321 articles in the different databases. Of these, six (1.86\%) were excluded because they were not scientific articles and $238(74.1 \%)$ duplicates were also excluded. After reading the titles and abstracts of 77 (32.4\%) articles, $55(71.4 \%)$ were excluded for the following reasons: $41(74.5 \%)$ were not based on or did not consider the Schema Therapy model; six (10.9\%) were not written in English, Portuguese or Spanish; five (9.1\%) did not present data on parental rearing styles; and three (5.45\%) were not empirical articles; achieving $81.81 \%$ concordance. Subsequently, the main evaluator and a third evaluator read the materials carefully and selected $22(28.5 \%)$ manuscripts that met the inclusion criteria. A flowchart illustrating the manuscript selection process is presented below (Figure 1).

Table 1 shows the general characteristics of the studies selected, including the first author and year of publication, the country where the research was carried out, the characteristics of the groups that comprised the samples (number and age), the objectives and the 
instruments used. It also shows the main results of each article and their respective limitations.

Among the 22 studies that investigated and characterized the effects of parental rearing styles and their relationship with Early Maladaptive Schemas, 36.3\% of the manuscripts referred to Asian samples, $7,8,14-17,20,26$ $27.27 \%$ referred to European samples, ${ }^{12,13,21-27} 18 \%$ referred to samples from North America ${ }^{11,19,28}$ and Latin America ${ }^{18}$ and $9.1 \%$ referred to samples from Oceania. ${ }^{9,10}$ Regarding sample characteristics, $68.1 \%$ of the studies had subjects aged between 16 and 70 years old, ${ }^{8-14,17,22-27}$ and another $22.7 \%$ evaluated university students. ${ }^{7,15,16,18,20}$ Only $31.8 \%$ of the 22 manuscripts' samples were composed of comparative groups. ${ }^{10,13,17,22-26}$

Except for the study conducted by Lumley et al., ${ }^{19}$ which measured EMS using the Schema Questionnaire for Children (SQC), all of the other studies assessed EMS using the Young Schema Questionnaire (YSQ). ${ }^{7,8,12-}$
14,17,18,20-25,27 The Young Parenting Inventory (YPI) was used to evaluate parental perception in $33.3 \%$ of the studies. $9,11,14-18,25,26$ Another instrument used was the Parental Bonding Instrument (PBI). ${ }^{7,16,20,22-24}$ It is noteworthy that the manuscripts employed a wide range of instruments for measuring parental perception, such as, the Parental Authoritative Questionnaire, ${ }^{7}$ the Bonding Parental Inventory, ${ }^{15}$ the Measure of Parental Style, ${ }^{10} \mathrm{EMBU},{ }^{12,13,21,27}$ the Child Report of Parenting Behavior Inventory, ${ }^{19}$ and the Parental Child Relationship Survey. ${ }^{20}$

In accordance with the eligibility criteria, the studies selected investigated variables other than EMS and perceptions of parental rearing styles, such as depressive symptoms, ${ }^{11,14,16,19,24,27}$ anxiety symptoms, ${ }^{16,19,21}$ eating psychopathologies, ${ }^{9,12,13}$ Personality Disorder, Post-Traumatic Stress Disorder (PTSD) ${ }^{10}$ and Drug Addiction (DA). ${ }^{17}$ With reference to studies that evaluated depressive symptoms, five used

Total found in data base search: 321

Psychnet: 12

BVS: 42

Scopus: 105

Web of Science: 26

PubMed: 136

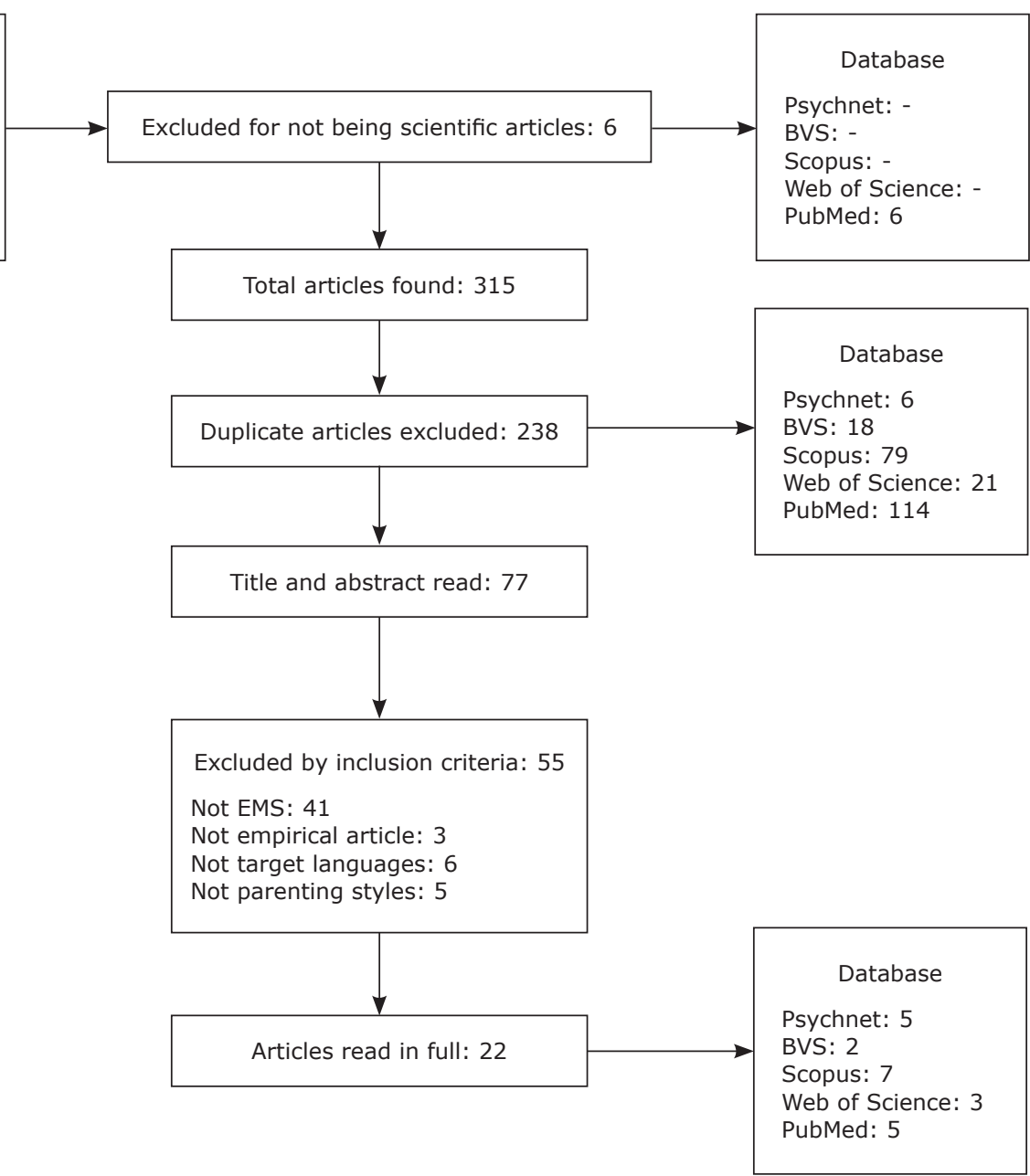

Figure 1 - Manuscript selection flowchart 
Table 1 - General characteristics of the studies selected

\begin{tabular}{|c|c|c|c|c|c|c|}
\hline Author & Country & Sample & Objective & Instruments & Main Results & Limitations \\
\hline Batool $^{7}$ & Pakistan & $\begin{array}{l}100 \text { university } \\
\text { students (young } \\
\text { adults) }\end{array}$ & $\begin{array}{l}\text { - Mediating role } \\
\text { of EMS between } \\
\text { perceptions } \\
\text { of parental } \\
\text { rearing styles } \\
\text { and symptoms } \\
\text { of personality } \\
\text { disorders }\end{array}$ & $\begin{array}{l}\text { 1. PAQ } \\
\text { 2. YSQ-SF } \\
\text { 3. PDQ }\end{array}$ & $\begin{array}{l}\text { - Permissive parenting style had positive } \\
\text { correlations with histrionic, narcissistic } \\
\text { and anti social personality disorders; } \\
\text { - Authoritarian parenting had positive } \\
\text { correlations with EMS and depressive } \\
\text { personality disorder; } \\
\text { - EMS had positive correlations with } \\
\text { histrionic, antisocial, narcissistic and } \\
\text { depressive personality disorder; } \\
\text { - EMS partially mediated between } \\
\text { permissive paternal parenting style } \\
\text { and narcissistic personality disorder } \\
\text { and between authoritarian paternal } \\
\text { parenting style and depressive } \\
\text { personality disorder. }\end{array}$ & $\begin{array}{l}\text { - Concentrated on four } \\
\text { personality disorders; } \\
\text { - Measured role of } \\
\text { overall schemas } \\
\text { instead of } \\
\text { investigating the } \\
\text { effects of the eighteen } \\
\text { schemas; } \\
\text { - Investigated the } \\
\text { entire phenomenon of } \\
\text { personality disorders } \\
\text { through the lens of } \\
\text { paternal malparenting; } \\
\text { - Generalizations cannot } \\
\text { be made. }\end{array}$ \\
\hline Beigi ${ }^{8}$ & Iran & $\begin{array}{l}\text { - } 50 \text { participants } \\
\text { with personality } \\
\text { disorder and ages } \\
\text { ranging from less } \\
\text { than } 20 \text { to over } \\
30 \text { years (mean } \\
\text { age: } 26 \text { ); and } \\
\text { their parents }\end{array}$ & $\begin{array}{l}\text { - To determine the } \\
\text { role of parents' } \\
\text { schemas in the } \\
\text { etiology of their } \\
\text { children's schemas } \\
\text { in different types } \\
\text { of personality } \\
\text { disorders }\end{array}$ & $\begin{array}{l}\text { 1. MCMI-III } \\
\text { 2. YSQ-SF }\end{array}$ & $\begin{array}{l}\text { - In the first cluster, VUL in children } \\
\text { correlated with VUL and DS schemas } \\
\text { in mother. The child's ED schema } \\
\text { correlated perfectly with ED in father; } \\
\text { - In the second cluster, VUL in children } \\
\text { correlated with AB, DS, FA, EM and } \\
\text { VUL in mother. The child's ED schema } \\
\text { correlated perfectly with father's ED } \\
\text { schema; } \\
\text { - In the third cluster, the VUL in the } \\
\text { child correlated with mother's VUL, AB, } \\
\text { MA, ISC and DS significantly. The ED } \\
\text { schema correlated perfectly with ED in } \\
\text { the father; } \\
\text { - MA schema in the father were } \\
\text { predictors of developing third cluster in } \\
\text { the child. SI schema in the mother was } \\
\text { a predictor of developing third cluster } \\
\text { in the child. SUB and VUL schemas in } \\
\text { the child predict the third cluster of } \\
\text { personality disorders. }\end{array}$ & $\begin{array}{l}\text { - The cross-sectional } \\
\text { design does not allow } \\
\text { causal attributions to } \\
\text { be made; } \\
\text { - Limited sample size; } \\
\text { - Self-report method. }\end{array}$ \\
\hline Brown ${ }^{9}$ & Australia & $\begin{array}{l}\text { - } 174 \text { participants } \\
\text { - } 18 \text { to } 65 \text { years }\end{array}$ & $\begin{array}{l}\text { - To investigate } \\
\text { whether } \\
\text { dysfunctional } \\
\text { schema coping } \\
\text { modes mediate } \\
\text { the relationship } \\
\text { between perceived } \\
\text { negative parenting } \\
\text { and the eating } \\
\text { disorder behaviors } \\
\text { of restricting, } \\
\text { binging, and } \\
\text { overcompensation } \\
\text { (purging and } \\
\text { overexercising) }\end{array}$ & $\begin{array}{l}\text { 1. YPI-R } \\
\text { 2. SMI } \\
\text { 3. EDDS }\end{array}$ & $\begin{array}{l}\text { - The perfectionistic overcontroller and } \\
\text { self-aggrandiser modes mediated } \\
\text { the relationships between perceived } \\
\text { negative parenting and compensatory } \\
\text { behavior. The compliant surrenderer } \\
\text { mode was found to mediate the } \\
\text { relationships between negative } \\
\text { parenting and both restricting } \\
\text { and compensatory behavior. The } \\
\text { detached protector and detached } \\
\text { self-soother modes further mediated } \\
\text { the relationships between perceived } \\
\text { negative parenting experiences and } \\
\text { both restriction and compensatory } \\
\text { behavior; } \\
\text { - Both restricting and compensatory } \\
\text { behavior were weakly correlated } \\
\text { with a variety of different perceived } \\
\text { negative parenting experiences. The } \\
\text { strongest correlations were seen } \\
\text { between Perfectionistic Overcontroller } \\
\text { and both controlling and conditional/ } \\
\text { narcissistic father, between Detached } \\
\text { Self-soother and belittling, emotionally } \\
\text { depriving and emotionally inhibited } \\
\text { mother and between both Compliant } \\
\text { Surrenderer and Detached Protector } \\
\text { and emotionally inhibited mother. } \\
\text { Restriction was weakly to moderately } \\
\text { correlated with all dysfunctional coping } \\
\text { modes except Bully/attack, with } \\
\text { the strongest correlation being with } \\
\text { Perfectionistic Overcontroller. Binge } \\
\text { eating was only weakly correlated } \\
\text { with a single mode - the Detached } \\
\text { Protector. Finally, compensatory } \\
\text { behavior was strongly correlated with } \\
\text { the Detached Protector, with weak to } \\
\text { moderate correlations with all other } \\
\text { dysfunctional coping modes. }\end{array}$ & $\begin{array}{l}\text { - Each of the behaviors } \\
\text { was only measured } \\
\text { with a single question; } \\
\text { - Only the coping mode } \\
\text { subscales of the } \\
\text { SMI were included, } \\
\text { and re-included } \\
\text { the Perfectionistic } \\
\text { Overcontroller coping } \\
\text { mode, after it being } \\
\text { excluded from the } \\
\text { original SMI; } \\
\text { - Self-report method; } \\
\text { - The cross-sectional } \\
\text { design; } \\
\text { - Perceptions of } \\
\text { parenting styles are } \\
\text { subjective. }\end{array}$ \\
\hline
\end{tabular}


Table 1 (cont.)

\begin{tabular}{|c|c|c|c|c|c|c|}
\hline Author & Country & Sample & Objective & Instruments & Main Results & Limitations \\
\hline Cockram $^{10}$ & Australia & $\begin{array}{l}\text { - } 220 \text { Vietnam } \\
\text { Veterans from } \\
\text { Australia and } \\
\text { New Zealand } \\
\text { - } 163 \text { with PTSD } \\
\text { - } 57 \text { without PTSD }\end{array}$ & $\begin{array}{l}\text { Study } 1: \\
\text { - To examine } \\
\text { relationships } \\
\text { between childhood } \\
\text { parenting } \\
\text { experiences, } \\
\text { EMS and PTSD } \\
\text { in a convenience } \\
\text { sample of male } \\
\text { Vietnam war } \\
\text { Veterans }\end{array}$ & $\begin{array}{l}\text { Study 1: } \\
\text { 1. DQ } \\
\text { 2. MOPS } \\
\text { 3. YSQ -L3 } \\
\text { 4. ASDS }\end{array}$ & $\begin{array}{l}\text { Study 1: } \\
\text { - Average parental style scores differed } \\
\text { significantly between PTSD and } \\
\text { no PTSD groups in both parenting } \\
\text { categories and in all subscales of the } \\
\text { MOPS; } \\
\text { - The PTSD group experienced greater } \\
\text { indifference, abuse and overcontrol } \\
\text { from both parents than the no PTSD } \\
\text { group; } \\
\text { - Veterans diagnosed with PTSD scored } \\
\text { higher on the YSQ-L3 and on the MPS } \\
\text { than veterans not diagnosed with } \\
\text { PTSD. } \\
\text { - VUL and EI schema discriminated } \\
\text { Significantly between veterans with } \\
\text { PTSD and those without PTSD. }\end{array}$ & $\begin{array}{l}\text { - Use of retrospective } \\
\text { accounts; } \\
\text { - Limits on how far to } \\
\text { generalize the study } \\
\text { results; } \\
\text { - Participants were } \\
\text { volunteers and not } \\
\text { randomly selected; } \\
\text { - Current PTSD status } \\
\text { was not measured in } \\
\text { the first study. }\end{array}$ \\
\hline Haugh $^{11}$ & USA & $\begin{array}{l}\text { - } 657 \text { university } \\
\text { students } \\
\text { - } 18 \text { to } 46 \text { years } \\
\text { old }\end{array}$ & $\begin{array}{l}\text { - To examine } \\
\text { the interaction } \\
\text { between childhood } \\
\text { maltreatment } \\
\text { and child's } \\
\text { temperament in } \\
\text { formation of EMS } \\
\text { - To examine EMS } \\
\text { as risk factors } \\
\text { for development } \\
\text { of depressive } \\
\text { symptoms }\end{array}$ & $\begin{array}{l}\text { 1. YSQ-SF-3 } \\
\text { 2. YPI } \\
\text { 3. ATQ-SF } \\
\text { 4. BDI-II }\end{array}$ & $\begin{array}{l}\text { - Negative affect and extraversion } \\
\text { temperament factors were significantly } \\
\text { related to depressive symptoms and } \\
\text { EMS domains; } \\
\text { - Temperament was shown to have a } \\
\text { significant influence on the indirect } \\
\text { effect of parenting on depressive } \\
\text { symptoms through EMS. } \\
\text { - Significant associations were found } \\
\text { between maladaptive parenting styles } \\
\text { and both EMS domains and depressive } \\
\text { symptoms; } \\
\text { - ED, Belittling, and Overprotective styles } \\
\text { were significantly and positively related } \\
\text { to EMS domains and BDI-II scores; } \\
\text { - ED parenting was most strongly } \\
\text { correlated to the RD domain; } \\
\text { - Overprotective parenting was most } \\
\text { strongly correlated with the IAP } \\
\text { domain; } \\
\text { - The influence of parenting on } \\
\text { depressive symptoms was shown to } \\
\text { be mediated by EMS (RD, and IAP } \\
\text { domains). }\end{array}$ & $\begin{array}{l}\text { - Only included } \\
\text { parenting, } \\
\text { temperament and } \\
\text { schema factors that } \\
\text { were most relevant to } \\
\text { depression; } \\
\text { - Self-report measures; } \\
\text { - The measure of } \\
\text { parenting reported } \\
\text { experiences from } \\
\text { when subjects were } \\
\text { children; } \\
\text { - Lack of diversity in the } \\
\text { sample; } \\
\text { - Non-clinical population } \\
\text { with depressive } \\
\text { symptoms (minimum } \\
\text { to moderate ranges); } \\
\text { - Participants only } \\
\text { reporting the mother } \\
\text { as primary caregiver. }\end{array}$ \\
\hline Jones $^{12}$ & UK & $\begin{array}{l}\text { - } 66 \text { females with } \\
\text { eating disorders } \\
\text { - } 16 \text { to } 59 \text { years } \\
\text { old }\end{array}$ & $\begin{array}{l}\text { - To examine } \\
\text { the possible } \\
\text { moderating role } \\
\text { of core beliefs in } \\
\text { the relationship } \\
\text { between parental } \\
\text { rearing behaviors } \\
\text { and eating } \\
\text { psychopathology }\end{array}$ & $\begin{array}{l}\text { 1. EDI } \\
\text { 2. YSQ-SF-3 } \\
\text { 3. SEMBU }\end{array}$ & $\begin{array}{l}\text { - SI, VUL, and SS schema moderated } \\
\text { the predictive influence of paternal } \\
\text { rejection on eating psychopathology; } \\
\text { - Both SI and VUL beliefs were found } \\
\text { to moderate the relationship between } \\
\text { paternal rejection and drive for } \\
\text { thinness; } \\
\text { - SS beliefs moderated the effect } \\
\text { of paternal rejection on body } \\
\text { dissatisfaction; } \\
\text { - Paternal rejection predicted body } \\
\text { dissatisfaction except when the } \\
\text { individual held intense, dysfunctional } \\
\text { beliefs about needing to meet other } \\
\text { people's needs. }\end{array}$ & $\begin{array}{l}\text { - Self-report measures; } \\
\text { - Retrospective measure } \\
\text { of parental rearing; } \\
\text { - The women were a } \\
\text { self-selected group } \\
\text { and had self reported } \\
\text { their current eating } \\
\text { psychopathology } \\
\text { status. }\end{array}$ \\
\hline Jones $^{13}$ & UK & $\begin{array}{l}\text { - } 66 \text { females with } \\
\text { current eating } \\
\text { psychopathology, } \\
16-59 \text { years old } \\
\text { - } 50 \text { female } \\
\text { volunteers in } \\
\text { a non-clinical } \\
\text { group, } 18-62 \\
\text { years old }\end{array}$ & $\begin{array}{l}\text { - To explore the } \\
\text { relationship } \\
\text { between } \\
\text { recollections } \\
\text { of paternal } \\
\text { rearing behavior } \\
\text { and eating } \\
\text { psychopathology } \\
\text { - To determine } \\
\text { whether specific } \\
\text { core beliefs would } \\
\text { act as mediators } \\
\text { between aspects } \\
\text { of parenting } \\
\text { and eating } \\
\text { symptomatology }\end{array}$ & $\begin{array}{l}\text { 1. EDI } \\
\text { 2. YSQ-SF-3 } \\
\text { 3. SEMBU }\end{array}$ & $\begin{array}{l}\text { - Negative recollections of paternal } \\
\text { rearing behaviors, and higher levels } \\
\text { of several core beliefs were related to } \\
\text { eating symptomatology; } \\
\text { - AB, DS and VUL schema were found } \\
\text { to mediate the influence of aspects of } \\
\text { paternal rearing behaviors on eating } \\
\text { psychopathology; } \\
\text { - Paternal rearing behaviors were } \\
\text { predictive of eating psychopathology; } \\
\text { - Perception of paternal overprotection is } \\
\text { predictive of drive for thinness; } \\
\text { - Perceived paternal rejection can lead } \\
\text { to the development of a combination of } \\
\text { fear that significant others will not be } \\
\text { able to continue providing emotional } \\
\text { support and to underlying feelings of } \\
\text { shame and inferiority. } \\
\text { - No associations were found between } \\
\text { eating psychopathology and } \\
\text { perceptions of parenting or core beliefs } \\
\text { within the non-clinical group }\end{array}$ & $\begin{array}{l}\text { - Self-report measures; } \\
\text { - Retrospective measure } \\
\text { of parental rearing; } \\
\text { - The women were a } \\
\text { self-selected group. }\end{array}$ \\
\hline
\end{tabular}


Table 1 (cont.)

\begin{tabular}{|c|c|c|c|c|c|c|}
\hline Author & Country & Sample & Objective & Instruments & Main Results & Limitations \\
\hline $\begin{array}{l}\text { Khajouei } \\
\text { Nia }^{14}\end{array}$ & $\begin{array}{l}\text { Iran and } \\
\text { India }\end{array}$ & $\begin{array}{l}\text { - } 200 \text { women } \\
\text { with depressive } \\
\text { symptoms } \\
-16 \text { to } 60 \text { years } \\
\text { old } \\
-100 \text { from India } \\
-100 \text { from Iran }\end{array}$ & $\begin{array}{l}\text { - To investigate } \\
\text { the contribution } \\
\text { of parental } \\
\text { rearing styles } \\
\text { to depression } \\
\text { symptoms of } \\
\text { women } \\
\text { - To examine the } \\
\text { role of early } \\
\text { maladaptive } \\
\text { symptoms as } \\
\text { mediators and } \\
\text { moderators of this } \\
\text { association }\end{array}$ & $\begin{array}{l}\text { 1. BDI } \\
\text { 2. YSQ-SF } \\
\text { 3. YPI }\end{array}$ & $\begin{array}{l}\text { - The association between parental } \\
\text { rearing styles and depressive } \\
\text { symptoms was not moderated by EMS; } \\
\text { - AB EMS had a mediating role in the } \\
\text { relationship between maternal rearing } \\
\text { style and depression in Iran; } \\
\text { - AB and PP EMS mediated the effects of } \\
\text { paternal rearing style and depression in } \\
\text { India; } \\
\text { - The correlation between childhood } \\
\text { experiences and depression in } \\
\text { adulthood was mediated by EMS. }\end{array}$ & - Only female sample. \\
\hline Kooraneh ${ }^{15}$ & Iran & $\begin{array}{l}\text { - } 357 \\
\text { undergraduate } \\
\text { students at } \\
\text { Islamic Azad } \\
\text { University }\end{array}$ & $\begin{array}{l}\text { - To predict EMS } \\
\text { using BPS (root } \\
\text { development) }\end{array}$ & $\begin{array}{l}\text { 1.YSQ-SF } \\
\text { 2. BPI }\end{array}$ & $\begin{array}{l}\text { - The best parenting style was } \\
\text { authoritarian, and most schemas } \\
\text { belong to the fields of RD, IA, and OVI, } \\
\text { respectively; } \\
\text { - The authoritarian parenting style could } \\
\text { positively predict EMS in the area of } \\
\text { RD, either could explain } 3.4 \% \text { of the } \\
\text { variance of EMS in the area of OD. } \\
\text { - The permissive parenting style could } \\
\text { not explain EMS in the areas of RD, } \\
\text { IAP, IL, OD or OVI; } \\
\text { - The authoritative parenting style could } \\
\text { negatively predict EMS in the area of } \\
\text { RD, and could explain } 3.4 \% \text { of the } \\
\text { variance of EMS in the area of OD, but } \\
\text { not in IAP, IL or OVI. }\end{array}$ & $\begin{array}{l}\text { - Self-report measure } \\
\text { and a student sample; } \\
\text { - The results are not } \\
\text { applicable to other } \\
\text { communities. }\end{array}$ \\
\hline Körük ${ }^{16}$ & Turkey & $\begin{array}{l}\text { - } 400 \text { university } \\
\text { students ( } 25 \% \\
\text { male and } 75 \% \\
\text { female) }\end{array}$ & $\begin{array}{l}\text { - To investigate } \\
\text { the relationships } \\
\text { between perceived } \\
\text { parenting parental } \\
\text { attachment styles } \\
\text { and psychological } \\
\text { symptoms }\end{array}$ & $\begin{array}{l}\text { 1. YPI } \\
\text { 2. PBI } \\
\text { 3. BSI }\end{array}$ & $\begin{array}{l}\text { - Pessimistic/fearful mother, } \\
\text { overprotective/worrywart father } \\
\text { and emotionally divesting father } \\
\text { perceptions meaningfullly predicted } \\
\text { depression and anxiety; } \\
\text { - Pessimistic/fearful mother and } \\
\text { belittling/captious mother perceptions } \\
\text { meaningfully predicted negative-self } \\
\text { symptoms; } \\
\text { - Pessimistic/fearful mother, } \\
\text { overprotective/worrywart father and } \\
\text { belittling/captious mother meaningfully } \\
\text { predicted somatization; } \\
\text { - Caring/controlling behaviors of the } \\
\text { father and protecting behaviors of } \\
\text { the mother meaningfully predicted } \\
\text { depression in the negative direction; } \\
\text { - Caring/controlling behaviors of the } \\
\text { mother and protecting behaviors of the } \\
\text { father meaningfully predicted anxiety } \\
\text { in the negative direction. } \\
\text { - Caring/controlling behaviors of the } \\
\text { mother and protecting, and caring/ } \\
\text { controlling behaviors of the father } \\
\text { meaningfully predicted negative-self } \\
\text { symptoms and hostility in the negative } \\
\text { direction. }\end{array}$ & $\begin{array}{l}\text { - Did not report } \\
\text { limitations. }\end{array}$ \\
\hline Jalali17 & Iran & $\begin{array}{l}\text { - } 56 \text { opioid } \\
\text { dependent males, } \\
20 \text { to } 45 \text { years } \\
\text { old } \\
\text { - } 56 \text { not opioid } \\
\text { dependent males, } \\
20 \text { to } 45 \text { years } \\
\text { old }\end{array}$ & $\begin{array}{l}\text { - The aim of } \\
\text { this study was } \\
\text { to examine } \\
\text { differences in } \\
\text { early maladaptive } \\
\text { schemas and } \\
\text { parenting origins } \\
\text { between opioid } \\
\text { abusers and non- } \\
\text { opioid abusers }\end{array}$ & $\begin{array}{l}\text { 1. SCID-I } \\
\text { 2. YSQ-L3 } \\
\text { 3. YPI }\end{array}$ & $\begin{array}{l}\text { - The means for all EMS in the clinical } \\
\text { group were higher than the control } \\
\text { group and this was especially more } \\
\text { apparent in AB, ED, SI, EG, ISC, SS, } \\
\text { AR, US and PU schemas. } \\
\text { - The two groups differed significantly in } \\
\text { terms of EMS, EMS domains; } \\
\text { - The clinical group had higher scores } \\
\text { than the control group in terms of } \\
\text { parenting origins; } \\
\text { - Approximately, all EMS were related } \\
\text { to their parenting origins. The only } \\
\text { exceptions, where differences in means } \\
\text { were not significant, were MA, DS, DI, } \\
\text { and FA in mothers' parenting origins, } \\
\text { and FA, DV and SS in fathers' parenting } \\
\text { origins } \\
\text { - Opioid abusers scored higher for EMS } \\
\text { and parenting origins than non-opioid } \\
\text { abusers and parenting origins were } \\
\text { related to their corresponding schemas. }\end{array}$ & $\begin{array}{l}\text { - All participants were } \\
\text { male. }\end{array}$ \\
\hline
\end{tabular}


Table 1 (cont.)

\begin{tabular}{|c|c|c|c|c|c|c|}
\hline Author & Country & Sample & Objective & Instruments & Main Results & Limitations \\
\hline Lucadame $^{18}$ & Uruguay & $\begin{array}{l}\text { - } 310 \text { Uruguayan } \\
\text { university } \\
\text { students }\end{array}$ & $\begin{array}{l}\text { - To analyze } \\
\text { whether EMS } \\
\text { act as mediators } \\
\text { between the } \\
\text { domains of early } \\
\text { parental styles } \\
\text { and development } \\
\text { of symptoms of } \\
\text { depression }\end{array}$ & $\begin{array}{l}\text { 1. YPI } \\
\text { 2. YSQ-L3 } \\
\text { 3. LSB-50 }\end{array}$ & $\begin{array}{l}\text { - For both parents, the EMS of AB, } \\
\text { SI and IS mediate the relationship } \\
\text { between early perceived parenting } \\
\text { styles (from the domains RD and IA) } \\
\text { and symptoms of depression for both } \\
\text { parents; } \\
\text { - EMS mediates the relationship between } \\
\text { parental styles and symptoms of } \\
\text { depression. }\end{array}$ & $\begin{array}{l}\text { - Self-report } \\
\text { instruments. }\end{array}$ \\
\hline Lumley $^{19}$ & Canada & $\begin{array}{l}-198 \text { boys and } \\
\text { girls (103 girls, } \\
95 \text { boys) } \\
-9 \text { to } 14 \text { years old }\end{array}$ & $\begin{array}{l}\text { - To investigate how } \\
\text { cognitive schema } \\
\text { organization } \\
\text { relates to parental } \\
\text { perception and } \\
\text { depressive } \\
\text { symptoms in early } \\
\text { adolescence }\end{array}$ & $\begin{array}{l}\text { 1. CDI } \\
\text { 2. MASC } \\
\text { 3. CSQ } \\
\text { 4. PDST } \\
\text { 5. CRPBI }\end{array}$ & $\begin{array}{l}\text { - There was no significant relationship } \\
\text { between anxiety symptoms and either } \\
\text { positive or negative EMS organization; } \\
\text { - Organization of positive and negative } \\
\text { EMS was significantly related to } \\
\text { depression symptoms; } \\
\text { - Negative EMS content was only related } \\
\text { with ethnicity; } \\
\text { - The analyses show that depression } \\
\text { symptoms were related with ethnicity } \\
\text { and that anxiety symptoms were } \\
\text { related with sex; } \\
\text { - High negative EMS scores were } \\
\text { associated with high depression scores; } \\
\text { - Low parental responsivity levels were } \\
\text { significantly associated with major } \\
\text { depression symptoms and high levels } \\
\text { of psychological control; } \\
\text { - Parental psychological control was } \\
\text { associated with race/ethnicity } \\
\text { - Parental responsivity emerged as the } \\
\text { only predictor of the NSO. }\end{array}$ & $\begin{array}{l}\text { - Sample composition: } \\
\text { data is not } \\
\text { generalizable to other } \\
\text { populations; } \\
\text { - Self-report } \\
\text { instruments. }\end{array}$ \\
\hline Monirpoor $^{20}$ & Iran & $\begin{array}{l}-345 \text { university } \\
\text { students }(218 \\
\text { females, } 127 \\
\text { males) }\end{array}$ & $\begin{array}{l}\text { - To assess } \\
\text { fathers' roles } \\
\text { as predictive of } \\
\text { early maladaptive } \\
\text { cognitive schemas }\end{array}$ & $\begin{array}{l}\text { 1. YSQ-SF } \\
\text { 2. PBI-FF } \\
\text { 3. PCRS }\end{array}$ & $\begin{array}{l}\text { - Father care and father emotional } \\
\text { involvement predicted } 20.7 \% \text { of the ED } \\
\text { schema variance; } \\
\text { - Father excessive support and emotional } \\
\text { interaction predicted } 9.3 \% \text { of the MA } \\
\text { schema variance, } 11.7 \% \text { of the SI } \\
\text { schema variance and } 13.4 \% \text { of the DF } \\
\text { schema variance; } \\
\text { - Father care and excessive support } \\
\text { predicted } 13.6 \% \text { of the SUB schema } \\
\text { variance. } \\
\text { - Father excessive support predicted } \\
0.9 \% \text { of the AB schema variance, } 2.4 \% \\
\text { of the EM self schema variance and } \\
1.5 \% \text { of the US schema variance; } \\
\text { - Positive father's affection predicted } \\
8.5 \% \text { of the FA schema variance and } \\
9.4 \% \text { of the DI schema variance; } \\
\text { - Father excessive support and positive } \\
\text { father's affection predicted } 5.9 \% \text { of the } \\
\text { VUL schema variance; } \\
\text { - Relationship with father predicted } 8.7 \% \\
\text { of the EI schema and } 5.5 \% \text { of the EM } \\
\text { schema; } \\
\text { - Relationship with father and lack of } \\
\text { child's anger toward father predicted } \\
8.9 \% \text { of the ISC schema }\end{array}$ & $\begin{array}{l}\text { - Did not report } \\
\text { limitations. }\end{array}$ \\
\hline Muris $^{21}$ & Netherlands & $\begin{array}{l}\text { - } 173 \text { non-clinical } \\
\text { adolescents }(87 \\
\text { boys and } 86 \\
\text { girls) } \\
\text { - } 12 \text { to } 15 \text { years } \\
\text { old }\end{array}$ & $\begin{array}{l}\text { To investigate } \\
\text { whether: } \\
\text { - Detrimental } \\
\text { parental rearing } \\
\text { behaviors are } \\
\text { associated with the } \\
\text { presence of EMS } \\
\text { - The personality } \\
\text { trait of neuroticism } \\
\text { is positively related } \\
\text { to such EMS } \\
\text { - Detrimental } \\
\text { parenting } \\
\text { behaviors and } \\
\text { neuroticism each } \\
\text { account for a } \\
\text { unique proportion } \\
\text { of the variance in } \\
\text { EMS scores } \\
\text { - EMS are } \\
\text { associated with } \\
\text { psychopathological } \\
\text { symptoms }\end{array}$ & $\begin{array}{l}\text { 1. YSQ-A } \\
\text { 2. EMBU-C for } \\
\text { children } \\
\text { 3. BFQC } \\
\text { 4. PQY }\end{array}$ & $\begin{array}{l}\text { - Detrimental rearing behaviors were } \\
\text { associated with the presence of } \\
\text { maladaptive schemas; } \\
\text { - The personality trait of neuroticism was } \\
\text { positively related to a broad range of } \\
\text { maladaptive schemas; } \\
\text { - Neuroticism and detrimental parental } \\
\text { rearing behaviors both accounted for } \\
\text { a unique proportion of the variance in } \\
\text { distorted thinking patterns; } \\
\text { - Maladaptive schemas were linked } \\
\text { to various types of psychological } \\
\text { symptoms, including symptoms } \\
\text { of anxiety disorders, depression, } \\
\text { disruptive behavior, eating problems } \\
\text { and substance use. } \\
\text { - Parental rearing behaviors accounted } \\
\text { for a significant proportion of the } \\
\text { variance in YSQ-A scores, except for } \\
\text { DI. }\end{array}$ & $\begin{array}{l}\text { - The study was cross- } \\
\text { sectional in nature; } \\
\text { - Sample of non-clinical } \\
\text { adolescents who } \\
\text { were predominantly } \\
\text { Caucasian, with } \\
\text { relatively high } \\
\text { educational levels; } \\
\text { - The sample was rather } \\
\text { small }(N=173 \text { ) and } \\
\text { as a result it was not } \\
\text { possible to perform } \\
\text { factor analysis on the } \\
\text { items of the YSQ-A; } \\
\text { - Self-report measures; } \\
\text { - Unclear whether a } \\
\text { questionnaire like the } \\
\text { YSQ-A truly measures } \\
\text { maladaptive schemas. }\end{array}$ \\
\hline
\end{tabular}


Table 1 (cont.)

\begin{tabular}{|c|c|c|c|c|c|c|}
\hline Author & Country & Sample & Objective & Instruments & Main Results & Limitations \\
\hline Pellerone $^{22}$ & Italy & $\begin{array}{l}\text { - } 248 \text { males (130 } \\
\text { with anti-social } \\
\text { personality } \\
\text { disorder, } 19 \text { to } 70 \\
\text { years old; } 118 \\
\text { healthy, } 20 \text { to } 70 \\
\text { years old) }\end{array}$ & $\begin{array}{l}\text { - To investigate } \\
\text { the presence of } \\
\text { cognitive schemas, } \\
\text { in a group of male } \\
\text { adult prisoners } \\
\text { - To explore whether } \\
\text { parental style } \\
\text { influences cognitive } \\
\text { patterns in a group } \\
\text { of offenders } \\
\text { - To investigate the } \\
\text { predictive variables } \\
\text { of these cognitive } \\
\text { schemas in adult } \\
\text { offenders }\end{array}$ & $\begin{array}{l}\text { 1. SCID-II } \\
\text { 2. PBI } \\
\text { 3. YSQ-L3 }\end{array}$ & $\begin{array}{l}\text { - The target group have an affectionate } \\
\text { constraint attachment with their } \\
\text { mother, while one third of the } \\
\text { population has a negligent attachment } \\
\text { with their father; } \\
\text { - Offenders scored significantly higher } \\
\text { than non-offenders on the level of } \\
\text { paternal control and the YSQ subscales. } \\
\text { - The study underlines the influence of } \\
\text { maternal care on most of the cognitive } \\
\text { schemas, and the role of father's } \\
\text { control in the tendency to SI and DS in } \\
\text { the offenders; } \\
\text { - Being an inmate, having a low level } \\
\text { of maternal care and a high level of } \\
\text { maternal control are predictive of the } \\
\text { tendency to social rejection, and being } \\
\text { an inmate with young age, reduced } \\
\text { maternal care and high maternal } \\
\text { control are predictive of IAP. }\end{array}$ & $\begin{array}{l}\text { - The results in no } \\
\text { way allow for casual } \\
\text { conjectures; } \\
\text { - All tests were self- } \\
\text { report; } \\
\text { - Small sample size. }\end{array}$ \\
\hline Pellerone ${ }^{23}$ & Italy & $\begin{array}{l}\text { - } 209 \text { adults } \\
(118 \text { males, } 91 \\
\text { females) } \\
\text { - } 20 \text { to } 60 \text { years } \\
\text { old }(M=37.52 ; \\
\text { SD }=11.42)\end{array}$ & $\begin{array}{l}\text { - To verify whether } \\
\text { being parents and } \\
\text { living at home } \\
\text { with parents affect } \\
\text { parenting style and } \\
\text { cognitive domains } \\
\text { - To examine how } \\
\text { variables of } \\
\text { parenting influence } \\
\text { cognitive styles } \\
\text { - To examine age } \\
\text { as moderating } \\
\text { variable of the } \\
\text { relation between } \\
\text { parenting styles } \\
\text { and cognitive } \\
\text { domains in a group } \\
\text { of adult men and } \\
\text { women }\end{array}$ & $\begin{array}{l}\text { 1. PBI } \\
\text { 2. YSQ }\end{array}$ & $\begin{array}{l}\text { - Being a younger adult male with } \\
\text { mother's parenting style characterized } \\
\text { by a lower level of nurturance is } \\
\text { predictive of the RD domain, whereas } \\
\text { being a younger adult woman, with } \\
\text { a higher level of maternal control is } \\
\text { predictive of the IL domain; } \\
\text { - The analysis of whether being parents } \\
\text { and living at home with parents affect } \\
\text { parenting or cognitive domains found } \\
\text { no significant effect. } \\
\text { - The type of maternal parenting affects } \\
\text { all domains except SI and SUB; } \\
\text { - Age moderates the correlation between } \\
\text { parenting behavior and maternal } \\
\text { nurturance and IAP domains. }\end{array}$ & $\begin{array}{l}\text { - The results in no } \\
\text { way allow for casual } \\
\text { conjectures; } \\
\text { - Did not use a measure } \\
\text { to account for socially } \\
\text { desirable responding } \\
\text { and/or the tendency to } \\
\text { minimize pathology; } \\
\text { - Did not use current } \\
\text { parental behaviors; } \\
\text { - Small sample size } \\
\text { that may have limited } \\
\text { the generalizability } \\
\text { of the findings and } \\
\text { the ability to identify } \\
\text { other differences in } \\
\text { maladaptive schemas. }\end{array}$ \\
\hline $\begin{array}{l}\text { Shah \& } \\
\text { Weller }{ }^{24}\end{array}$ & England & $\begin{array}{l}\text { - } 60 \text { depressive } \\
\text { individuals ( } 17 \\
\text { men, } 43 \text { women) } \\
\text { - } 67 \text { healthy } \\
\text { individuals ( } 33 \\
\text { men, } 34 \text { women) }\end{array}$ & $\begin{array}{l}\text { - To investigate the } \\
\text { possible mediating } \\
\text { role of core beliefs } \\
\text { in depressive } \\
\text { parental relations } \\
\text { - To examine } \\
\text { whether this } \\
\text { relationship } \\
\text { between parental } \\
\text { rearing styles } \\
\text { and depression } \\
\text { in adulthood is } \\
\text { mediated by the } \\
\text { EMS }\end{array}$ & $\begin{array}{l}\text { 1. PBI } \\
\text { 2. YSQ } \\
\text { 3. BDI }\end{array}$ & $\begin{array}{l}\text { - The experimental group recalled less } \\
\text { affectionate and more overprotective } \\
\text { parental care, in relation to the control } \\
\text { group; } \\
\text { - The depressed group were } \\
\text { differentiated by poorer perceived } \\
\text { parenting (low care and high } \\
\text { overprotection); } \\
\text { - DS, SS and ISC EMS were more } \\
\text { present in the experimental group. } \\
\text { - DI, VUL, US and EI EMS mediated the } \\
\text { relationship between maternal bond } \\
\text { and paternal overprotection and levels } \\
\text { of depression in the experimental } \\
\text { group. }\end{array}$ & $\begin{array}{l}\text { - Did not report } \\
\text { limitations. }\end{array}$ \\
\hline $\operatorname{Simon}^{25}$ & Hungary & $\begin{array}{l}-47 \text { transsexuals: } \\
30 \mathrm{MF} \\
17 \mathrm{FM}(\mathrm{M}= \\
27.06 \text { years) } \\
-157 \text { controls: } \\
43 \text { men } \\
114 \text { women ( } \mathrm{M}= \\
23.6 \text { years) }\end{array}$ & $\begin{array}{l}\text { - To characterize } \\
\text { MF and FM } \\
\text { transsexuals in } \\
\text { psychopathology, } \\
\text { core } \\
\text { conceptualizations } \\
\text { of the self and } \\
\text { the world, } \\
\text { and parenting } \\
\text { experiences by } \\
\text { comparing them } \\
\text { to controls of the } \\
\text { same and the } \\
\text { opposite sex } \\
\text { - To delineate } \\
\text { differences } \\
\text { in MF and FM } \\
\text { transsexuals in } \\
\text { these three areas }\end{array}$ & $\begin{array}{l}\text { 1. YSQ } \\
\text { 2. YPI } \\
\text { 3. SC-90-R }\end{array}$ & $\begin{array}{l}\text { - Subjects with GID demonstrated a level } \\
\text { of psychiatric distress comparable to } \\
\text { that of controls. } \\
\text { - Subjects with GID display elevated } \\
\text { scores, however, on multiple EMS } \\
\text { compared to nontranssexual subjects, } \\
\text { indicating feelings of isolation, } \\
\text { emotional deprivation and an urge } \\
\text { to meet others' needs, with MF } \\
\text { transsexuals also conceptualizing } \\
\text { themselves as more vulnerable and } \\
\text { deficient than controls. } \\
\text { - Parenting experiences of transsexual } \\
\text { subjects were characterized by } \\
\text { increased maternal dominance, } \\
\text { emotional abuse and neglect compared } \\
\text { to controls, with males being exposed } \\
\text { to a disengaged maternal style and } \\
\text { more paternal emotional neglect and } \\
\text { criticism. } \\
\text { - Both MF and FM transsexuals were } \\
\text { made to feel that they will inevitably } \\
\text { fail in areas of achievement. }\end{array}$ & $\begin{array}{l}\text { - Retrospective } \\
\text { analyses. } \\
\text { - Diagnosis interviews. } \\
\text { - Not utilizing a } \\
\text { psychiatric control } \\
\text { group. }\end{array}$ \\
\hline
\end{tabular}


Table 1 (cont.)

\begin{tabular}{|c|c|c|c|c|c|c|}
\hline Author & Country & Sample & Objective & Instruments & Main Results & Limitations \\
\hline Soygüt ${ }^{26}$ & Turkey & $\begin{array}{l}\text { - } 94 \text { undergraduate } \\
\text { students, } 17 \text { to } \\
26 \text { years old }\end{array}$ & $\begin{array}{l}\text { - To examine the } \\
\text { relationship } \\
\text { between the } \\
\text { perception of } \\
\text { parenting styles } \\
\text { and interpersonal } \\
\text { schemas } \\
\text { - To investigate } \\
\text { the role of } \\
\text { interpersonal } \\
\text { schemas in } \\
\text { mediating between } \\
\text { the perception of } \\
\text { parenting style } \\
\text { and psychological } \\
\text { symptoms }\end{array}$ & $\begin{array}{l}\text { 1. YPI } \\
\text { 2. ISQ } \\
\text { 3. SCL-90-R }\end{array}$ & $\begin{array}{l}\text { - Perceived parenting styles have } \\
\text { predictive power for a number of } \\
\text { interpersonal schemas; } \\
\text { - Parenting perceptions showing } \\
\text { maximum positive correlations with } \\
\text { depression were belittling/captious } \\
\text { mother, ruling/former mother, } \\
\text { overprotective/worrywart mother and } \\
\text { belittling/captious father. } \\
\text { - Positive correlations with anxiety were } \\
\text { found to be belittling/captious mother, } \\
\text { overprotective/worrywart mother, } \\
\text { pessimistic/fearful mother, and ruling/ } \\
\text { former father. } \\
\text { - The Hostility situation of interpersonal } \\
\text { schemas played a mediating role } \\
\text { between psychological symptoms } \\
\text { and normative, belittling/criticizing, } \\
\text { pessimistic/worried parenting styles } \\
\text { on the mother forms; and normative, } \\
\text { belittling/criticizing, emotionally } \\
\text { depriving, pessimistic/worried, } \\
\text { punitive, and restricted/emotionally } \\
\text { inhibited parenting styles on the father } \\
\text { forms of the scales. }\end{array}$ & $\begin{array}{l}\text { - Limited number of } \\
\text { undergraduates in } \\
\text { sample; } \\
\text { - Assessments were } \\
\text { limited to self-reports. }\end{array}$ \\
\hline Thimm 27 & Norway & $\begin{array}{l}\text { - } 108 \text { participants } \\
\text { ( } 75 \% \text { women }) \\
\text { - } 19 \text { to } 68 \text { years } \\
\text { old }(M=40.3)\end{array}$ & $\begin{array}{l}\text { - To investigate } \\
\text { whether EMS } \\
\text { mediate the } \\
\text { relationship } \\
\text { between perceived } \\
\text { parental rearing } \\
\text { style and } \\
\text { personality disorder } \\
\text { symptomatology }\end{array}$ & $\begin{array}{l}\text { 1. S-EMBU } \\
\text { 2. YSQ-L3 } \\
\text { 3. DSM-IV, } \\
\text { ICD-10 } \\
\text { DIP-Q } \\
\text { 4. GAFS } \\
\text { 5. BDI }\end{array}$ & $\begin{array}{l}\text { - All schemas were associated with the } \\
\text { three personality disorder clusters; } \\
\text { - The BDI are related to maternal } \\
\text { rejection, to the five schema domains } \\
\text { and the personality disorder clusters A, } \\
\text { B and C; } \\
\text { - The results showed that EMS mediated } \\
\text { the relationship between parental } \\
\text { rearing styles and personality disorder } \\
\text { symptoms; } \\
\text { - Rejection from both parents and less } \\
\text { emotional warmth from mother were } \\
\text { significantly related to cluster A and B } \\
\text { personality pathology, whereas cluster } \\
\text { C symptoms were associated with } \\
\text { paternal rejection; } \\
\text { - RD, OD, IAP, OVI were significantly } \\
\text { related to parenting rejection. }\end{array}$ & $\begin{array}{l}\text { - Retrospective } \\
\text { analyses. } \\
\text { - Self-report } \\
\text { instruments. } \\
\text { - Sample composition } \\
\text { - data cannot be } \\
\text { generalized to other } \\
\text { populations. }\end{array}$ \\
\hline Wright ${ }^{28}$ & USA & $\begin{array}{l}-301 \\
\text { undergraduate } \\
\text { students }(143 \\
\text { men, } 158 \\
\text { women }) ; M= \\
20.37 \text { years }\end{array}$ & $\begin{array}{l}\text { - To study the long- } \\
\text { term influences } \\
\text { of parental } \\
\text { emotional abuse } \\
\text { and emotional } \\
\text { neglect in young } \\
\text { adults, in relation } \\
\text { to dissociative, } \\
\text { anxiety and } \\
\text { depression } \\
\text { symptoms } \\
\text { - To identify which } \\
\text { symptoms were } \\
\text { mediated by the } \\
\text { EMS }\end{array}$ & $\begin{array}{l}\text { 1. CAST-6 } \\
\text { 2. LEQ } \\
\text { 3. YSQ } \\
\text { 4. TSC-40 }\end{array}$ & $\begin{array}{l}\text { - VUL, SS and DS EMS mediated the } \\
\text { relationship between emotional neglect } \\
\text { and anxiety and depression symptoms. } \\
\text { - VUL and DS EMS were mediated in } \\
\text { the relationship between the child's } \\
\text { emotional neglect and dissociative } \\
\text { symptoms. Emotional neglect was } \\
\text { related to dissociative symptoms and } \\
\text { mediated by DV and VUL EMS. } \\
\text { - Sexual abuse was also a significant } \\
\text { predictor of dissociation. } \\
\text { - Emotional abuse and neglect, alcoholic } \\
\text { parents and income were significant } \\
\text { predictors of anxiety and depression } \\
\text { and were mediated by VUL, DS and SS } \\
\text { EMS. } \\
\text { - Emotional abuse was significantly } \\
\text { correlated to VUL, SS and DS EMS. } \\
\text { Emotional abuse and neglect have } \\
\text { a greater psychological impact than } \\
\text { physical abuse and neglect. }\end{array}$ & $\begin{array}{l}\text { - The data found cannot } \\
\text { be generalized to } \\
\text { clinical or community } \\
\text { populations. } \\
\text { - Retrospective } \\
\text { analyses. }\end{array}$ \\
\hline
\end{tabular}

$\mathrm{AB}=$ abandonment; $\mathrm{AR}$ = approval-seeking/recognition-seeking; ASDS = The Acute Stress Disorder Scale; ATQ-SF = Adult Temperament Questionnaire-Short Form; BDI = Beck's Depression Inventory; BFQC = The Big Five Questionnaire for Children; BPI = Baumrind's Parenting Inventory; BSI = Brief Symptoms Inventory; CRPBI = Child Report of Parent Behavior Inventory; CAST-6 = Children of Alcoholics Screening Test; CDI = Children's Depression Inventory; CSQ = Children Schema Questionnaire; DIP-Q = DSM-IV ICD-10 Personality Questionnaire; DPI = dependence/incompetence; DQ = Demographic Questionnaire; DS = defectiveness/shame; $E D=$ emotional depravation; $E D D S=$ Eating Disorder Diagnostic Scale; $E D I=$ Eating Disorder Inventory; EG = entitlement/grandiosity; $\mathrm{EI}=$ emotional inhibition; $\mathrm{EM}=$ Enmeshment; EMBU-C = EMBU for children; EMS = Early Maladaptive Schemas; ENT = Entitlement; FA = failure to achieve; FM = female to male; GAFS = Global Assessment of Functioning Scale; GID = gender identity disorder; IAP = Impaired Autonomy and Performance; IL = impaired limits; ISC = insufficient self-control; ISQ = Interpersonal Schema Questionnaire; LEQ = Lifetime Experiences Questionnaire; LSB-50 = The Brief Symptom Check List; $\mathrm{M}=$ mean; $\mathrm{MA}=$ mistrust and abuse; MASC = Multicomponent Anxiety Scale for Children - 10; MCMI-III = Millon Clinical Multi-Axial Inventory; MF $=$ male to female; MOPS = Measure of Parental Style; NSO = Negative Schema Organization; OD = Other Direction; OVI = over-vigilance and inhibition; PAQ = Parental Authority Questionnaire; PBI = Parental Bounding Instrument; PBI-FF = Parental Bounding Instrument - Father Form; PCRS = Parent-Child Relationship Survey; PDQ = Personality Diagnostic Questionnaire; PDST = Psychological Distance Scaling Task; PQY = Psychopathology Questionnaire for Youths; PU = Punishment; RD = rejection and disconnection; SC-90-R = Symptom Checklist-0-R; SCL-90-R = Symptom Checklist-90-R; SD = standard deviation; SEMBU = EMBU short form; SI = social isolation; SMI = Schema Mode Inventory; SS = self-sacrifice; SUB = subjugation; TSC-40 = Trauma Symptom Checklist; US = unbalanced standards; VUL = vulnerability; YPI = Young Parenting Inventory; YPI-R = Young Parental Inventory Revised; YSQA = Agedown version of the YSQ; YSQ-LF = Young Schema Questionnaire - Long Form; YSQ-S3 = Young Schema Questionnaire-Short Form Version 3. 
the Beck Depression Inventory (BDI), ${ }^{11,14,16,25}$ Lumley et al. ${ }^{19}$ used the Children's Depression Inventory (CDI) to evaluate depressive symptoms in children and only one of them contained an experimental group with major depressive disorder. ${ }^{14}$ Finally, only Haugh et al. ${ }^{11}$ investigated temperament, using the Adult Temperament Questionnaire-Short Form (ATQ-SF).

In seven studies, relations were found between depression and poor parenting styles, such as authoritarian parenting ${ }^{7}$; emotional deprivation and excessive parental control ${ }^{11}$; maternal pessimism, paternal overprotection and emotional alienation ${ }^{16}$; low parental care and overprotection ${ }^{24}$; emotional neglect, alcoholic parents and income ${ }^{28}$; and maternal rejection. ${ }^{27}$ Additionally, Lumley et al. ${ }^{19}$ found an association between low levels of parental responsiveness, symptoms of major depression and high levels of psychological control. The structural organization of both tightly-interconnected negative schemas and loosely-interconnected positive schemas were significantly associated with depressive symptoms.

It should be noted that the studies also revealed that dysfunctional parenting is related to development of pathological symptoms of depressive personality, ${ }^{7}$ A, B and C clusters of personality disorders 8,27 and, more specifically, of antisocial personality disorder. ${ }^{22}$ As observed by Beigi et al., ${ }^{8}$ this can be explained by the type of child-rearing, such as permissive and authoritative parenting, ${ }^{7}$ negligible attachment, ${ }^{22,23}$ parental rejection and overprotection and deficient parental host, as indicated by Thimm. ${ }^{27}$ Besides the personality symptoms, poor parenting styles were related to development of several EMS, in $63.6 \%$ of the studies. ${ }^{7,10-13,17,20-23,25-28}$

Simon et al. ${ }^{25}$ assessed the possible repercussions of parental functioning in groups of transsexuals (Maleto-Female [MF]/Female-to-Male [FM]) in comparison to control groups (men and women), noting that MF transsexuals reported a higher number of adverse parenting experiences and a more negative view of self and others, compared to FM transsexuals and the control groups. With regard to Early Maladaptive Schemas in transsexual groups, the study inferred that the coerced suppression of their own sense of self for years, social exclusion and rejection of the need to be accepted by members of the other sex seemed to lead to high levels of interpersonal sensibility and contributed as important social factors in their development. On the other hand, both groups displayed higher independence from social feedback with lesser need to gain recognition from others. ${ }^{25}$

In parallel, the results also showed that MF transsexuals were more likely to develop psychiatric symptoms and described their mothers as less caring, less affective and more controlling during their childhood, when compared with controls. In turn, MF transsexuals saw their mothers as abusive and unreliable and with insufficient autonomy and achievement. MF transsexuals described their fathers as less caring, less available, less reliable and more critical and depreciative. ${ }^{25}$

EMS mediated the relationship between parental rearing styles and/or parental education and dysfunctional symptoms over the course of personality development in $66.6 \%$ of the studies. Among the symptoms investigated, we highlight personality disorder symptoms, ${ }^{7,27}$ depression, ${ }^{11,14,18,24}$ eating psychopathologies, ${ }^{13}$ and, finally, we found mediation of EMS in the relationship between negligent and abusive parental rearing styles - which were also identified as predictors - and dissociative, anxiety and/or depressive symptoms. ${ }^{28}$ Moreover, compliant surrender mode was found to mediate negative parenting and restrictive and compensatory behaviors in an Australian sample with eating disorder. ${ }^{9}$

In terms of specific EMS, the most prevalent EMS in the studies were vulnerability, $, 12,20,24,25,27$ dependence/ incompetence, ${ }^{20,24,27}$ and failure, ${ }^{20,25,27}$ from the second domain (impaired autonomy and performance), as well as abandonment ${ }^{13,14,20,22}$ and emotional deprivation, ${ }^{8,20,25}$ related to the first domain (disconnection/rejection). Additionally, parental control, $, 10,16,21-23$ emotional abuse $^{3,10,25,28}$ and rejection ${ }^{4,12,13,21,27}$ were the most frequent parenting styles.

\section{Discussion}

During personality development, environmental, social and biological variables interfere with the construction and activation of schematic patterns of functioning. ${ }^{2}$ Amongst these variables, the present study focused on parental rearing style.

Maladaptive personality patterns start to be formed the moment a child begins to interact with the world and are shaped by life experiences throughout the child's development. ${ }^{2}$ Carvalho \& Silva ${ }^{6}$ state that parental rearing styles have the capacity to minimize or maximize the impact of other variables on personality development. Therefore, the aim of this article was to conduct a systematic review of studies related to the repercussions for personality development of parental rearing styles and examine possible relationships between parenting styles and the development of EMS.

The 22 manuscripts included in this study presented data that reveal that poor parenting had negative 
effects on the personality development of the samples studied. The authors observed the relationships between parenting styles and depressive and anxiety symptoms, eating disorders and personality disorders. The results of these studies show a significant presence of EMS as potential mediators between the two variables. $7,11,13,14,18,28$ In agreement with what has been reported in other manuscripts, parental neglect is considered a relevant variable for development of depression, ${ }^{29}$ and the impact of maltreatment in childhood can be mediated by cognitive vulnerability, which includes negative attributional styles and maladaptive schemas. ${ }^{30}$

This is coherent with Young's theory ${ }^{2}$ regarding the influence of early experiences in the process of schema development and consolidation, considering parental rearing styles as one of the most important sources of early fruitful or damaging experiences. As a whole, the studies reviewed demonstrate that the negative repercussions of neglect, abuse and poor parenting response during childhood and a child's difficulty in having his/her core emotional needs met ${ }^{2}$ are connected.

For a child to become a psychologically healthy adult, his/her parents must be able to meet emotional needs common to every child, and which are considered essential to a healthy personality development. ${ }^{2}$ These needs are distributed across five different domains: acceptance and connection; autonomy and performance; realistic limits; the right to express thoughts, emotions and feelings; and spontaneity and play. ${ }^{2}$ In other words, in order to create a positive environment for the development of a healthy personality, it is important that parental rearing style be assertive and respect needs that are specific to the chronology of human development. Otherwise, the probability of the individual developing psychological or psychiatric symptoms increases, which may lead to diagnosis of a personality disorder in adulthood.7,8,22,27 As such, the bibliographic review conducted by Carvalho \& Silva ${ }^{6}$ shows a remarkable relationship between parental rearing styles, EMS and traces of what may be the individual's personality functioning in the future.

According to the Schema Therapy model, EMS are dimensional, that is, they can be more or less severe and pervasive depending on the extent to which they have been generalized. This generalization is due to activation of the same cognitions, emotions and bodily sensations through different life experiences, normally involving relevant figures in the individual's remote environment. When this is the case, activation and, consequently, perpetuation of schemas is facilitated, and these schemas become more central to the individual's personality. According to the model, the way a person copes with schema activation tends to become the foundation of most psychiatric disorders. ${ }^{2}$

The Schema model proposes that the way an individual copes in adulthood with schematic activation is likely to be a fairly faithful representation of the way he/she coped in childhood with the damaging situations/ experiences that form the foundation on which the EMS were developed. Young's ${ }^{2}$ studies also suggest that at the time that the coping mechanisms that have since become maladaptive were developed in childhood, they probably represented the most effective or adaptable way the child found to survive and preserve himself/ herself from the adverse situations experienced with important figures in that period. ${ }^{2}$

This reveals how childhood experiences and coping strategies may be linked to maladaptive behaviors and psychopathological symptoms in adult life. To exemplify, we highlight the study by Brown et al., ${ }^{9}$ which sought to investigate whether coping strategies were mediators of the relationship between perceived negative parenting experiences and eating disorders. The findings reported confirm the theoretical hypotheses and consolidate the view that mechanisms of coping with hypercompensation, avoidance and resignation appear to play a role in maintaining the symptoms of eating disorders and that there are multiple complex relationships between them and EMS that merit investigation.

In the present study, when mentioning the act of trying to preserve, or protect, oneself, the authors do not refer to any ability that the child might have to prevent these adverse experiences from contributing to development of EMS. Considering that children have the right to have their basic needs met and that is parents' duty to meet them, ${ }^{2}$ what the authors are referring to when discussing preservation are behaviors that can minimize the distress and suffering caused by these needs not being met. In other words, these behaviors represent an adaptation to the harmful elements of the remote environment.

Moreover, especially when referring to parental rearing styles, the development of EMS can be thought of as a reaction/adaptation to these parental rearing behaviors. It can be considered that the parents have a special ability to have their children adapt to their style, instead of having them opposed to it (even in the presence of extremely harmful and adverse stimuli), given the substantiality of their role for their children's survival. Parents play such an important role because of the nature of their bond with their children. Evolutionary researchers like Bowlby ${ }^{31}$ and Trivers ${ }^{32}$ studied, respectively, the importance of this bond and what determines and influences the parental investment that influences the bond. 
When observing child behavior, one can perceive that children strive to find ways of having at least part of their needs met, and, normally through trial and error, they, very intuitively, work out how to do this with their parents. This movement can be seen as an adaptation to their parents, as the children's reaction, with the tools they have, to the parents' rearing styles, so they can soften the way the parents' behaviors reverberate in their inner world, or at least make it more bearable.

Analyzing the importance of parental rearing styles in personality development, one could hypothesize that, in evolutionary terms, even with a certain amount of deprivation and suffering, it would be more advantageous for children (in terms of survival) to adapt to their parents' style (to whom they are attached, and who are normally attached to them) rather than not to do so. This does not mean, however, that this adaptation is a matter of choice or that there are necessarily any alternatives to it, but it considers that maybe children tend to behave, intuitively, in a way that maximizes meeting of their needs and preserves the bond with caregivers .

Drawing from clinical experience, the authors noted that, even after repeated abuse and/or neglect situations, children's attitudes towards their parents are likely to remain mostly positive, forgiving and obedient (especially at an early age). There seems to be a special need for reconciliation between absolutely distinct, and oftentimes dichotomic, images a child has of his/her mother or father, who, depending on the emotional state the parent is in (depressed, irritated, detached $X$ euthymic, calm, connected, etc.), the child can love or hate. Thus, for instance, seeing himself/herself as someone who deserves punishment or neglect could serve as a powerful tool for reduction of an incredibly distressing cognitive dissonance: seeing the person who your life depends on as incapable or not sufficiently emotionally connected to you to want or be able to meet your most basic emotional needs.

In their study about vulnerability and depression, Ingram \& Ritter $^{33}$ found evidence that children raised in a household where they are neglected by the mother are more prone to develop depression when adults and to have negative emotions and cognitions about themselves. These authors also found that these children are likely to have a predominantly negative self-image, and that this way of looking at themselves may have been developed as a reaction to parental rearing style from the mother's side. In this study, Ingram \& Ritter ${ }^{33}$ suggest that, if a child is being raised by a neglectful mother, he/she may begin to internalize what he/she sees as being a maternal view (of the child) that would be coherent with the attitude of not taking good care of this child, who thus starts to develop representations of himself/herself that are coherent with the perception of not being worthy of care and nurturance - which is in agreement with the description of EMS from the first domain, Disconnection and Rejection. ${ }^{2}$

Two studies reported specific social and cultural variables that could have contributed to schema construction. In the study with transsexuals, the feeling of social exclusion and the need to be accepted by members of the same sex were considered factors relevant ${ }^{25}$ to development of EMS. In the opposite direction, interesting but isolated data suggested that an overprotective/anxious parenting style, hypothetically dysfunctional, ${ }^{2}$ was perceived as functional and could lead to an expected and positive interpersonal cycle in Turkey's collectivistic society. ${ }^{26}$ Notwithstanding, this speculative interpretation about the role, influence and impact of culture and social experiences in the development of EMS or adaptive behavior, which has been emerging spontaneously, should be investigated in new studies assessing this relationship.

With regard to limitations, $59 \%$ of the studies referred to the characteristics of the samples investigated and the fact that the results could not be generalized. $7,8,10,11,13-15,17,21,27,28$ Small sample sizes may have limited their ability to detect further differences and larger sample sizes might therefore enable future studies to contribute more, allowing for more finegrained analyses. Furthermore, half of the studies presented limitations related to the use of self-reporting tools, which may contribute to biased responses and may increase the likelihood of association between the measures used. $8,9,11-13,15,19,21,22,26,27$

Use of instruments of retrospective analysis was considered a limitation in $31.8 \%$ of the studies, since participants may recall their most recent parenting experiences, be influenced by schemas currently in operation, facilitate distortions and allow inferences about perceived parenting behaviors. ${ }^{10,11,13,23,25,27,28}$ One alternative would be to conduct longitudinal studies, which could minimize this effect if they evaluated the present moment - although memory distortions may still occur anyway, considering that the participant would not be answering questions about the present moment.

Other limitations reported were the cross-sectional study designs, ${ }^{8,9,21-23}$ since no conclusions can be drawn on cause-effect relations between the variables investigated. An appropriate research study design would ideally include a prospective cohort study or multi-method approach, for example. Finally, just three manuscripts did not mention limitations. ${ }^{16,20,24}$

Not many articles were found that met the inclusion criteria for the present study, which goes to show the 
scarcity of published research in this area, despite the relevance of the topic. It is important to note that the data obtained from the manuscripts in this systematic review are the fruit of studies conducted on several continents, hence allowing a general mapping of what is being investigated, even considering the small samples. Comparative studies would be extremely relevant, since cultural, social and demographic aspects could broaden understanding of the phenomena. In conclusion, it is suggested that future research be conducted to broaden and deepen knowledge about the formation of personality structures, with the objective of providing information that can promote care and prevention strategies in early childhood.

\section{Disclosure}

No conflicts of interest declared concerning the publication of this article.

\section{References}

1. Benchaya MC, Bisch NK, Moreira TC, Ferigolo M, Barros HMT. Nonauthoritative parents and impact on drug use: the perception of adolescent children. J Pediatr. 2011;87:238-44.

2. Young JE, Klosko JS, Weishaar ME. Terapia do esquema: guia de técnicas cognitivo-comportamentais inovadoras. Porto Alegre: Artmed; 2008.

3. Hutz CS, Bardagi MP. Indecisão profissional, ansiedade e depressão na adolescência: a influência dos estilos parentais. Psico-USF. 2006;11:65-73.

4. Rinhel-Silva CM, Constantino EP, Rondoini CA. Família, adolescência e estilos parentais. Estud. psicol. 2012;29:221-30.

5. Salvo CG, Silvares EFM, Toni, PM. Práticas educativas como forma de predição de problemas de comportamento e competência social. Estud Psicol. 2005;22:187-95.

6. Carvalho MSD, Silva BMB. Estilos parentais: um estudo de revisão bibliográfica. Rev Psicol Foco. 2014;6:22-42.

7. Batool N, Shehzadi H, Riaz MN, Riaz MA. Paternal malparenting and offspring personality disorders: mediating effect of early maladaptive schemas. J Pak Med Assoc. 2017;67:556-60.

8. Beigi NA, Askari $H$. Interaction of parent-child schemas in different types of personality disorders. Int J Adv Biotechnol Res. 2016;4:1039-46.

9. Brown JM, Selth $S$, Stretton A, Simpson S. Do dysfunctional coping modes mediate the relationship between perceived parenting style and disordered eating behaviours? J Eat Disord. 2016;4-27.

10. Cockram DM, Drummond PD, Lee CW. Role and treatment of early maladaptive schemas in Vietnam veterans with PTSD. Clin Psychol Psychother. 2010;7:165-82.

11. Haugh JA, Miceli M, DeLorme J. Maladaptive parenting, temperament, early maladaptive schemas, and depression: a moderated mediation analysis. J Psychopathol Behav Assess. 2016;39:103-16.

12. Jones C, Harris G, Leung, L. Parental rearing behaviours and eating disorders: the moderating role of core beliefs. Eat Behav. 2005;6:355-64.

13. Jones $\mathrm{C}$, Leung $\mathrm{N}$, Harris, G. Father-daughter relationship and eating psychopathology: the mediating role of core beliefs. $\mathrm{Br}$ J Clin Psychol. 2016;45:319-30.
14. Khajouei-Nia M, Sovani A, Forooshani GR. Exploring correlation between perceived parenting styles, early maladaptive schemas, and depression among women with depressive symptoms in Iran and India - role of early maladaptive schemas as mediators and moderatos. Iran Red Crescent Med J. 2014;16:e17492.

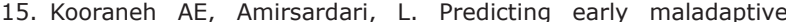
schemas using Baumrind's Parenting Styles. J Psychopathol Behav Assess. 2015;9:e952.

16. Körük S, Öztürk A, Kara A. The predictive strength of perceived parenting and parental attachment styles on psychological symptoms among Turkish university students. Int J Instruction. 2016;9:215-30.

17. Jalali MR, Zargar M, Salavati M, Kakavand AR. Comparison of early maladaptive schemas and parenting origins in patients with opioid abuse and non-abusers. Iran J Psychiatry Behav Sci. 2011;6:54-60.

18. Lucadame R, Cordero S, Daguerre L. El papel mediador de los esquemas desadaptativos tempranos entre los estilos parentales y los síntomas de depresión. Psicol Conductual. 2017;25:27595.

19. Lumley MN, Dozois DJA, Hennig KH, Marsh A. Cognitive organization, perceptions of parenting and depression symptoms in early adolescence. Cognit Ther Res. 2012;36:300-10.

20. Monirpoor N, Gholamyzarch M, Tamaddonfard M, Khoosfi $H$, Ganjali AR. Role of father-child relational quality in early maladaptive schemas. Int J High Risk Behav Addict. 2012;1:504.

21. Muris, P. Maladaptive schemas in non-clinical adolescents: relations to perceived parental rearing behaviours, big five personality factors and psychopathological symptoms. Clin Psychol Psychother. 2006;13:405-13.

22. Pellerone M, Craparo G, Tornabuoni. Relationship between parenting and cognitive schemas in a group of male adult offenders. Front Psychol. 2016;7:302.

23. Pellerone M, Iacolino C, Mannino G, Formica I, Zabbara SM. The influence of parenting on maladaptive cognitive schema: a cross-sectional research on a group of adults. Psychol Res Behav Manag. 2017;10:47-58.

24. Shah RC, Waller G. Parental style and vulnerability to depression: the role of core beliefs. J Nerv Ment Dis. 2000;188:19-25.

25. Simon L, Zsolt U, Fogd D, Czobor P. Dysfunctional core beliefs, perceived parenting behavior and psychopathology in gender identity disorder: a comparison of male-to-female, female-tomale transsexual and nontranssexual control subjects. J Behav Ther Exp Psychiatry. 2011;42:38-45.

26. Soygüt G, Cakir Z. The mediating role of the interpersonal schemas between parenting styles and psychological symptoms: a schema focused view. Turk Psikiyatri Derg. 2009;20:144-52.

27. Thimm JC. Mediation of early maladaptive schemas between perceptions of parental rearing style and personality disorder symptoms. J Behav Ther Exp. 2009;41:52-9.

28. Wright MO, Crawford E, Del Castillo D. Childhood emotional maltreatment and later psychological distress among college students: the mediating role of maladaptive schemas. Child Abuse Neglect. 2009;33:59-68.

29. Gibb BE, Abramson LY, Alloy LB. Emotional maltreatment from parents, verbal peer victimization, and cognitive vulnerability to depression. Cognit Ther Res. 2004;28:1-21.

30. Ingram RE, Ritter J. Vulnerability to depression: cognitive reactivity and parental bonding in high-risk individuals. J Abnorm Psychol. 2000;109:588-96.

31. Bowlby J. Attachment and loss: loss, sadness and depression. New York: Basic Books; 1980.

32. Trivers R. Parental investment and sexual selection. In: Campbell $B$, editor. Sexual selection and the descent of man. Chicago: Aldine-Atherton; 1972. p. 52-95.

33. Ingram RE. Origins of cognitive vulnerability to depression. Cognit Ther Res. 2003;27:77-88.

\section{Correspondence:}

Lissia Ana Basso

Av. Osvaldo Aranha, 1022/ 910, Bom Fim

90035-191 Porto Alegre, RS - Brazil

Tel.: +55 (51) 998301456

E-mail: lissiabasso7@gmail.com 